\title{
Nutritional Diversity and Antioxidant Activity of Two Indigenous Quince Ecotypes from Rawalakot, Azad Jammu and Kashmir
}

\author{
Noosheen Zahid (D), ${ }^{1}$ Mehdi Maqbool $\mathbb{D}^{1},{ }^{1}$ Majid Mahmood Tahir $\left(\mathbb{D},{ }^{2}\right.$ Abdul Hamid $\left(\mathbb{D},{ }^{1}\right.$ \\ Aqeel Ahmad, ${ }^{3}$ Muhammad Shafique Khalid, ${ }^{4}$ Haseeb ur Rehman, ${ }^{5}$ Nasir Masood, ${ }^{4}$ \\ Shahid Iqbal Awan, ${ }^{6}$ Javaid Riffat Khan, ${ }^{1}$ Asgar Ali, ${ }^{7}$ and Syed Zulfiqar Ali Shah ${ }^{1}$ \\ ${ }^{1}$ Department of Horticulture, Faculty of Agriculture, University of Poonch, Rawalakot, Azad Jammu and Kashmir, Pakistan \\ ${ }^{2}$ Department of Soil and Environmental Sciences, Faculty of Agriculture, University of Poonch, Rawalakot, \\ Azad Jammu and Kashmir, Pakistan \\ ${ }^{3}$ Department of Agronomy, Faculty of Agriculture, University of Poonch, Rawalakot, Azad Jammu and Kashmir, Pakistan \\ ${ }^{4}$ Department of Environmental Sciences, COMSATS University, Islamabad, Vehari Campus, Pakistan \\ ${ }^{5}$ Department of Agronomy, Bahauddin Zakariya University, Multan, Pakistan \\ ${ }^{6}$ Plant Pathology and Plant-Microbe Biology, Cornell University, Geneva, New York 14456, USA \\ ${ }^{7}$ Centre of Excellence for Postharvest Biotechnology, University of Nottingham, Malaysia Campus, Jalan Broga, Semenyih 43500, \\ Selangor, Malaysia
}

Correspondence should be addressed to Noosheen Zahid; noosheen.zahid@upr.edu.pk

Received 20 June 2021; Revised 12 August 2021; Accepted 1 September 2021; Published 26 September 2021

Academic Editor: Francisca Hernández

Copyright @ 2021 Noosheen Zahid et al. This is an open access article distributed under the Creative Commons Attribution License, which permits unrestricted use, distribution, and reproduction in any medium, provided the original work is properly cited.

\begin{abstract}
Quince fruit is mostly used to produce functional products. Recently, the value of this crop has increased due to demand as industrial raw material. The state of Azad Jammu and Kashmir and specifically Rawalakot, District Poonch, is blessed with climatic conditions which are very much suitable for quince production, and therefore, a huge plantation could be found in wild. In this regard, this study was designed to collect two different accessions of quince (apple-shaped quince (ASQ) and pear-shaped quince (PSQ)) from three different locations (Dhamni (elevation: $5431 \mathrm{ft}$ ), Shamsabad (elevation: $5374 \mathrm{ft}$ ), and Drake (elevation: $3378 \mathrm{ft}$ )) of Rawalakot, District Poonch, and analyze their physicochemical and mineral nutrients of fruit and the soil. Correlation coefficients were established pairwise. Results showed that physicochemical nutrients were significantly $(P \leq 0.05)$ higher in ASQ fruits as compared with PSQ fruits. Further, fruits collected from location at higher elevation (Dhamni) showed better results as compared with fruits collected from lower elevations. Moreover, increased amount of nitrogen contents in the soil resulted in increased fruit weight. Similarly, fruit quality indices and bioactive compounds showed a positive correlation with the increased soil nutrient contents. These prediction models for quality of quince could be useful in guiding plant nutrition status and for enhancing fruit production in this region.
\end{abstract}

\section{Introduction}

Fruits and vegetables are rich source of functional food such as antioxidants [1]. Fruits rich in antioxidants and minerals have intensified consumers interest due to anticancerous and anti-inflammatory properties [2]. Among different fruits, quince (Cydonia oblonga) is getting popularity due to its positive effects on human health such as antiulcerative, anti-inflammatory, antimicrobial, anticarcinogenic, and antiallergic effects [3]. Quince is highly rich in crude fiber, organic acid, and minerals such as calcium and phosphorus [4]. Due to the health promoting properties, quince might act as a tonic for brain and heart [5]. Around 70 quince cultivars are grown globally [6]. Among them, the most important cultivars of quince are Spahan, Pineapple, Botermo, 
Ekmek, Morova, Portugal, Orage, Van Deman, Meeh, Champion, and Smyrna [7].

Quince fruit is not appreciated in its raw form at unripe stage because of bitterness in taste and hard and astringent pulp; however, flavor becomes acceptable at ripen stage [8]. It is mainly used in jams, jellies, and marmalades. But the fruit is recognized as the inhibitor of $\alpha$-amylase which reflects its potential as a raw food material and its use in pharmaceutical industry [9].

The quality attributes of fruits are very much dependent on various factors such as genotypes or cultivars, environmental conditions, and growing location [10]. In Azad Jammu and Kashmir, particularly in Rawalakot, only two quince cultivars, that is, apple-shaped (Cydonia oblonga subspecies maliformis) and pear-shaped (Cydonia oblonga subspecies pyriformis), are present, while no information regarding their nutritional mapping is documented up till now. Therefore, this study was conducted to examine nutritional value, antioxidants activity, and mineral contents of different quince accessions or ecotypes in relation to growing location and soil fertility. The results will provide information about quince fresh consumption or jams or marmalades of high nutritional value. Additionally, the findings of the study will be helpful for plant breeders for selection of suitable cultivars for cultivar improvement.

\section{Materials and Methods}

2.1. Field Site Description. Quince ecotypes were collected from three different locations of Rawalakot, that is, Dhamni (latitude 73N.8972, longitude 33E.5132, and elevation $5431 \mathrm{ft}$ ), Shamsabad (latitude 73N.4534, longitude 33E.5132, and elevation $5374 \mathrm{ft}$ ), and Drake (latitude 73N.7781, longitude 33E.8240, and elevation $3378 \mathrm{ft}$ ). Three apple-shaped quinces (ASQ) and three pear-shaped quinces (PSQ) plants were selected from each location. After that, five different branches (north, south, east, west, and middle) of each plant were tagged. After ripening, three fruits per branch were harvested and transported to the Laboratory of the Department of Horticulture, Faculty of Agriculture, University of Poonch Rawalakot, for analysis.

In addition to fruit analysis, soils from each location were also sampled from the root zone $(0-30 \mathrm{~cm}$ depth) of each tree.

2.2. Physical Analysis. Fruit weight of selected fruit was measured with the help of weighing balance in grams (g).

\subsection{Fruit Quality Indices}

2.3.1. Titratable Acidity (TA). TA of quince sample was done by titration method. Briefly, $5 \mathrm{~g}$ pulp from selected fruits was homogenized with the help of mortar and pestle followed by mixing with $20 \mathrm{ml}$ of distilled water and then filtered with muslin cloth to obtain pure extract. The pure extract $(5 \mathrm{ml})$ was titrated with sodium hydroxide solution and phenolphthalein. This titration continues until end point reaches light pink color. The color persists for 10 seconds. Results were then expressed in \% of ascorbic acid.

2.3.2. Total Soluble Solids (TSS). TSS was done by using a hand refractometer (Kyoto Company, Japan). A single drop of juice from each sample was mounted on the prism of dry refractometer and data was recorded in percent.

\subsection{Biochemical Analysis}

2.4.1. Crude Fiber. Crude fiber in quince was estimated by method given by Association of Official Analytical Chemists [5]. Fruit sample ( $5 \mathrm{~g}$ ) was dried in a hot oven until persistent weight. These dried samples were digested in sulphuric acid and sodium hydroxide solution (1.25\%), respectively. These samples were again washed followed by drying in a furnace (model: Sx-2-5-10) at 500 or $550^{\circ} \mathrm{C}$ till white ash.

2.4.2. Total Ash Content. Fruit sample ( $5 \mathrm{~g})$ was weighed in a porcelain dish and placed in a muffle furnace (model: SX-2$5-10)$ at $100^{\circ} \mathrm{C}$ for removal of moisture; then the temperature was increased after every hour by $50^{\circ} \mathrm{C}$ and sustained at $500-550^{\circ} \mathrm{C}$ for 4 to 5 hours until fruit sample converts to white ash. After complete burning, the residues were cooled and weighed.

2.4.3. $\mathrm{pH}$. $\mathrm{pH}$ in quince sample was assessed by using $\mathrm{pH}$ meter (model: WTW 82362 inoLab, Germany). Calibration of $\mathrm{pH}$ meter was done with $\mathrm{pH} 4.0$ and 9.0 buffers.

2.4.4. Vitamin C. Assessment of vitamin $C$ in each sample was determined using a UV-vis spectrophotometer (model: VU-4000). Fruit sample (20 mg) was extracted by using $5 \mathrm{~mL}$ of metaphosphoric acid solution (4\%). This mixture was agitated for at room temperature for 45 minutes followed by filtration with Whatman filter paper No. 1. These extracts were then transferred in $10 \mathrm{ml}$ tubes and the volume was made to $10 \mathrm{ml}$ by adding 2,6-dichlorophenol dye. The absorbance was determined spectrophotometrically (model: VU-4000) at $515 \mathrm{~nm}$. Vitamin C was expressed as $\mathrm{mg}$ of vitamin $\mathrm{C}$ per $100 \mathrm{~g}$ fresh weight.

2.4.5. Total Phenols. Folin-Ciocalteu's Reagent $(2.5 \mathrm{~mL}$ of $7.0 \%)$, sodium carbonate solution $(2.0 \mathrm{ml}$ of $7.5 \%)$, and $0.5 \mathrm{~mL}$ of fruit juice were mixed. The mixture was incubated at $45^{\circ} \mathrm{C}$ for 40 minutes and absorbance was measured at $765 \mathrm{~nm}$ using spectrophotometer (model: VU-4000). Results were then expressed in $\mu \mathrm{g}$ of gallic acid per $100 \mathrm{~g}$ fresh weight of fruit [10].

2.4.6. Total Flavonoids. Fruit pulp $(0.5 \mathrm{mg})$ was mixed with methanolic $\mathrm{AlCl}_{3} \cdot 6 \mathrm{H}_{2} \mathrm{O}(1.5 \mathrm{ml})$ in airtight tubes and retained in dark for 15 minutes. Absorbance was measured at $430 \mathrm{~nm}$ using spectrophotometer (model: UV-4000) and the results were expressed as mmol of quercetin equivalent per $100 \mathrm{~g}$ fresh weight. 
2.4.7. Total Antioxidant Activity. Total antioxidant activity was measured by using ferric reducing antioxidant power (FRAP) assay. The FRAP reagent contains $10 \mathrm{mM}$ TPTZ solution $(2 \mathrm{ml})$ in $40 \mathrm{mM} \mathrm{HCl}, 20 \mathrm{mM} \mathrm{FeCl}_{3}(20 \mathrm{mM})$, and $0.03 \mathrm{mM}$ acetate buffer $(25 \mathrm{ml}), \mathrm{pH}$ 3.6. FRAP reagent $(3 \mathrm{ml})$ was mixed with $40 \mu \mathrm{L}$ of fruit juice incubated in dark $\left(37^{\circ} \mathrm{C}\right)$ for $4 \mathrm{~min}$. Absorbance was recorded at $593 \mathrm{~nm}$ and the results were expressed as mg per $100 \mathrm{~g} \mathrm{FW}$ of fruit.

2.5. Mineral Analysis of Fruit and Soil. Nitrogen was determined using Kjeldahl apparatus. Sample $(5 \mathrm{~g})$ was digested by using a $1.5 \mathrm{~mL}$ of triacid digest $\left(\mathrm{HClO}_{4}: \mathrm{HNO}_{3}\right.$ : $\mathrm{H}_{2} \mathrm{SO}_{4}$ ) in a digester. The temperature of the digester was increased gradually and maintained at $360^{\circ} \mathrm{C}$ for three hours. The samples were remained in digestion tubes until a clear solution is obtained [11]. Phosphorous contents were determined colorimetrically by using Nessler's reagent and vanadomolybdophosphoric acid yellow color method [12].

Mineral elements (copper, iron, and zinc) of fruit were determined with atomic absorption spectrophotometer (Perkin Elmer, Analyst 700). For this purpose, hot air-dried $1 \mathrm{~g}$ samples were mixed with $5 \mathrm{~mL}$ of $\mathrm{HNO}_{3}$. The mixture was then heated on a hot plate (SCILOGEX, Model MSH289-Pro) at $80-90^{\circ} \mathrm{C}$ for 2 hours. Hydrogen peroxide $(3-5 \mathrm{ml})$ was then added in the boiled mixture until a clear solution obtained. The solution is then filtered with filter paper having Millipore $<0.45 \mu \mathrm{m}$. The filtrate was then mixed with distilled water to make a volume of $25 \mathrm{ml}$. Blank samples were also prepared under same conditions [13].

Soil $\mathrm{pH}$ and electrical conductivity were determined by using $\mathrm{pH}$ meter and microprocessor conductivity meter, respectively, whereas soil organic matter was determined by chromic acid oxidation method.

2.6. Statistical Analysis. Descriptive statistics were used to analyze collected data (Statistix 8.1). Means were then subjected to analysis of variance (2-way ANOVA) for mean comparisons. Tukey's test at $95 \%$ confidence level $(P \leq 0.05)$ was used to discriminate mean values among three different locations and two different ecotypes. Pearson's correlation coefficient analysis was carried out to understand the relationship between soil fertility and fruit quality indices.

\section{Results}

3.1. Fruit Weight. Data regarding fruit weight of two quince ecotypes at different elevations was recorded and analyzed and there was a statistically significant difference $(P \leq 0.05)$ among shapes and elevations (Figure 1(a)). Highest fruit weight was observed at higher elevation (Dhamni) with PSQ. It is clear from observation that the weight of fruit increases with the increase in elevation. The positive correlation between soil $\mathrm{N}$ contents and fruit weight was observed (Figure 1(b)). It was observed that, with one unit increase in soil $\mathrm{N}$ contents, the increase in fruit weight is 1.15528 units (Figure 1(b)).
3.2. Fruit Quality Indices. Balance of acidity and sugars in fruits are considered as fruit quality indices and these indices are specific to the cultivar. Data regarding TA and TSS of two quince ecotypes at different elevations was recorded and analyzed statistically. A significant difference $(P \leq 0.05)$ among shapes and elevations was observed (Table 1 ). Maximum TA (1.38\%) was observed in PSQ followed by ASQ (1.35\%) at highest location (Dhamni). However, maximum TSS was recorded in PSQ (14.4\%) followed by ASQ at highest location (Table 1).

3.2.1. Vitamin C, Crude Fiber, $p H$, and Total Ash Content. Results regarding vitamin $\mathrm{C}$ content showed a significant $(P \leq 0.05)$ difference among the quinces harvested from different locations, whereas no significant difference was observed among the two ecotypes of quince fruit (Table 2). The highest value of vitamin C was recorded in PSQ at highest altitude (Dhamni), whereas the lowest vitamin $\mathrm{C}$ was recorded in lowest location (Drake) for both quince ecotypes (Table 2).

Results of $\mathrm{pH}$ showed a significant $(P \leq 0.05)$ difference was observed among two quince ecotypes (Table 2). $\mathrm{pH}$ of quince fruit normally ranges between 3.3 and 3.5. In our results, highest $\mathrm{pH}$ (3.49) was noted in PSQ at lower altitude, whereas the minimum $\mathrm{pH}$ was recorded in ASQ at highest elevation (Table 2).

A significant $(P \leq 0.05)$ difference was observed in crude fiber among two quince ecotypes and three different elevations (Table 2). Highest value (2.78\%) of crude fiber was recorded in PSQ at highest altitude (Dhamni) followed by ASQ $(2.66 \%)$ at highest altitude, while low percentage (1.69\%) of crude fiber was recorded in ASQ at lowest altitude (Table 2).

A significant $(P \leq 0.05)$ difference was observed in ash content (\%) among two quince ecotypes and three different elevations (Table 2). The highest value (3.50\%) of ash content was recorded in PSQ at highest altitude (Dhamni) followed by ASQ (3.31\%) at highest altitude, while low percentage (2.40\%) of ash content was recorded in ASQ at lowest altitude (Table 2).

3.2.2. Bioactive Compounds (Total Phenols, Total Flavonoids, and Total Antioxidants). Figure 2 shows a decreased trend of total phenols (Figure 2(a)), total flavonoids (Figure 2(b)), and total antioxidants (Figure $2(\mathrm{c})$ ), with a decrease in elevation, and also shows a significant difference $(P \leq 0.05)$ of total phenolics, flavonoids, and antioxidants among different shapes. Figure 2(a) shows highest total phenols in PSQ at Dhamni (highest elevation) followed by total phenols in ASQ at highest elevation. Total flavonoids were maximum in PSQ which was at par with ASQ at highest elevation (Dhamni) (Figure 2(b)).

3.2.3. Mineral Analysis. Results in Table 3 show that high N and $\mathrm{P}$ are present in both quince cultivars, whereas $\mathrm{Cu}, \mathrm{Fe}$, and $\mathrm{Zn}$ are also present in quince fruit. These mineral contents decreased significantly $(P \leq 0.05)$ at lower elevation 


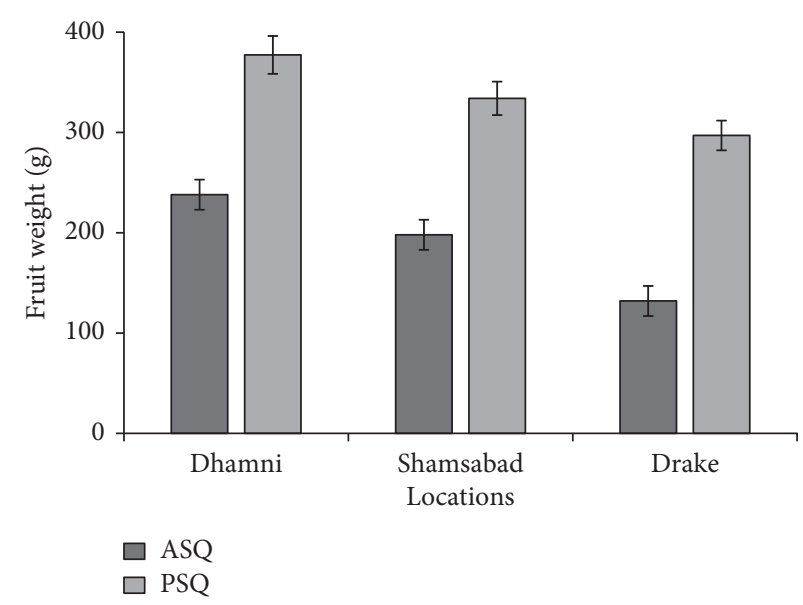

(a)

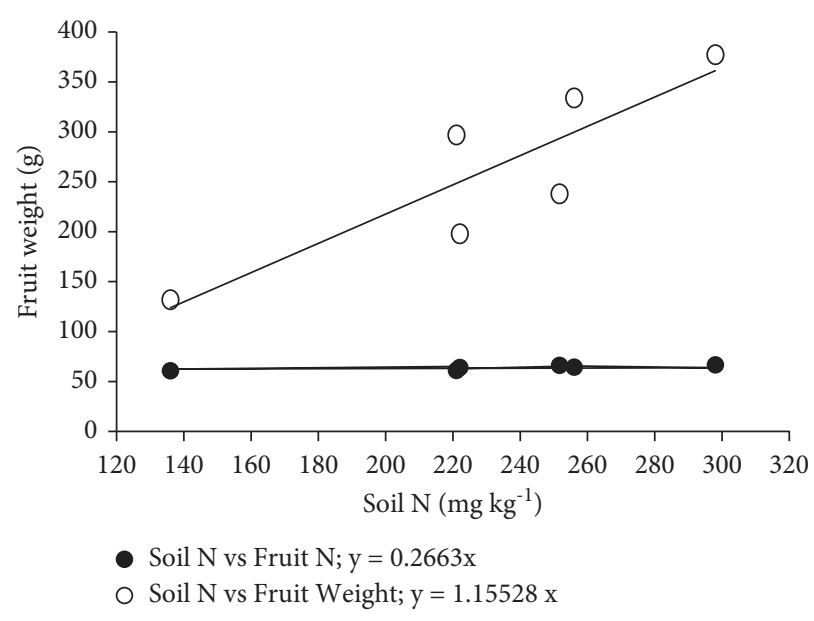

(b)

FIGURE 1: Effect of different elevations on (a) fruit weight of two different quince ecotypes and (b) correlation among soil N contents and fruit weight of two quince ecotypes. ASQ: apple-shaped quince; PSQ: pear-shaped quince. Vertical bars indicate standard error of means $( \pm$ SEM) for three replicates.

TABLE 1: Titratable acidity (TA) and total soluble solids (TSS) of two quince ecotypes from three different locations of Rawalakot, Azad Jammu and Kashmir.

\begin{tabular}{|c|c|c|c|c|}
\hline \multirow{2}{*}{ Locations } & \multicolumn{2}{|c|}{ TA (\%) } & \multicolumn{2}{|c|}{ TSS (\%) } \\
\hline & ASQ & PSQ & ASQ & PSQ \\
\hline Dhamni & $1.35 \mathrm{a}$ & $1.38 \mathrm{a}$ & $12.06 \mathrm{~b}$ & $14.40 \mathrm{a}$ \\
\hline Shamsabad & $1.29 \mathrm{~b}$ & $1.30 \mathrm{ab}$ & $8.93 c$ & $14.13 \mathrm{ab}$ \\
\hline Drake & \multirow{2}{*}{\multicolumn{2}{|c|}{$1.23 \mathrm{c}$}} & $8.00 \mathrm{c}$ & $14.03 \mathrm{ab}$ \\
\hline LSD & & & \multicolumn{2}{|c|}{2.09} \\
\hline
\end{tabular}

Note. Means with different letters are significantly different $(P \leq 0.05)$ from each other. ASQ: apple-shaped quince; PSQ: pear-shaped quince; LSD: LSD value.

TABle 2: Vitamin C, pH, crude fiber, and ash content of two quince ecotypes from three different locations of Rawalakot, Azad Jammu and Kashmir.

\begin{tabular}{|c|c|c|c|c|c|c|c|c|}
\hline \multirow[t]{2}{*}{ Locations } & \multicolumn{2}{|c|}{$\begin{array}{l}\text { Vitamin C (mg } 100 \mathrm{~g}^{-1} \\
\text { fresh weight of fruit) }\end{array}$} & \multicolumn{2}{|c|}{$\mathrm{pH}$} & \multicolumn{2}{|c|}{ Crude fiber (\%) } & \multicolumn{2}{|c|}{ Ash content (\%) } \\
\hline & ASQ & PSQ & ASQ & PSQ & ASQ & PSQ & ASQ & PSQ \\
\hline Dhamni & $24.04 \mathrm{a}$ & $24.32 \mathrm{a}$ & $3.31 \mathrm{c}$ & $3.34 \mathrm{bc}$ & $2.66 \mathrm{~b}$ & $2.78 \mathrm{a}$ & $3.31 \mathrm{~b}$ & $3.50 \mathrm{a}$ \\
\hline Shamsabad & $23.23 \mathrm{a}$ & $23.51 \mathrm{a}$ & $3.35 \mathrm{c}$ & $3.37 \mathrm{ab}$ & $2.30 \mathrm{~d}$ & $2.43 \mathrm{c}$ & $2.67 \mathrm{~cd}$ & $2.76 \mathrm{c}$ \\
\hline Drake & $20.44 \mathrm{~b}$ & $20.81 \mathrm{~b}$ & $3.44 \mathrm{~b}$ & $3.49 \mathrm{a}$ & $1.69 \mathrm{f}$ & $1.80 \mathrm{e}$ & $2.40 \mathrm{e}$ & $2.51 \mathrm{de}$ \\
\hline LSD & \multicolumn{2}{|c|}{1.61} & \multicolumn{2}{|c|}{0.12} & \multicolumn{2}{|c|}{0.10} & \multicolumn{2}{|c|}{0.17} \\
\hline
\end{tabular}

Note. Means with different letters are significantly different $(P \leq 0.05)$ from each other. ASQ: apple-shaped quince; PSQ: pear-shaped quince; LSD: LSD value.

in both quince cultivars. Results showed that high $\mathrm{N}$ and $\mathrm{P}$ are present in both quince cultivars (Table 3). Meanwhile $\mathrm{Cu}$, $\mathrm{Fe}$, and $\mathrm{Zn}$ are also present in quince fruit. These mineral contents decreased significantly $(P \leq 0.05)$ at lower elevation in both quince cultivars. Table 4 shows Pearson correlation coefficients, which represent highly significant $(P \leq 0.05)$ relationship among all mineral contents. Increased amount of zinc is responsible for synthesis of carbohydrates and also participates in different chemical reactions.

All these mineral elements are highly positively correlated with each other (Table 4). With the increase in one unit increase of $\mathrm{N}$ contents in soil, fruit TA and TSS increased up to 0.854 and 0.787 units, respectively. Correlation results of soil $\mathrm{P}$ showed that, with one unit increase in $\mathrm{P}$ contents, TA increased up to 0.964 units and TSS increased up to 0.527 units. Similarly, every unit increase of each mineral content in soil results in increase in fruit quality indices (Table 4).

\section{Discussion}

Fruit quality has been well observed with the increase in elevation. This could be due to the fact that fruit weight might be influenced by climatic conditions, environmental factors, and availability of the sunlight. Moreover, it could be enlightened with response to higher rate of transpiration which is associated with higher irradiance and could give an 


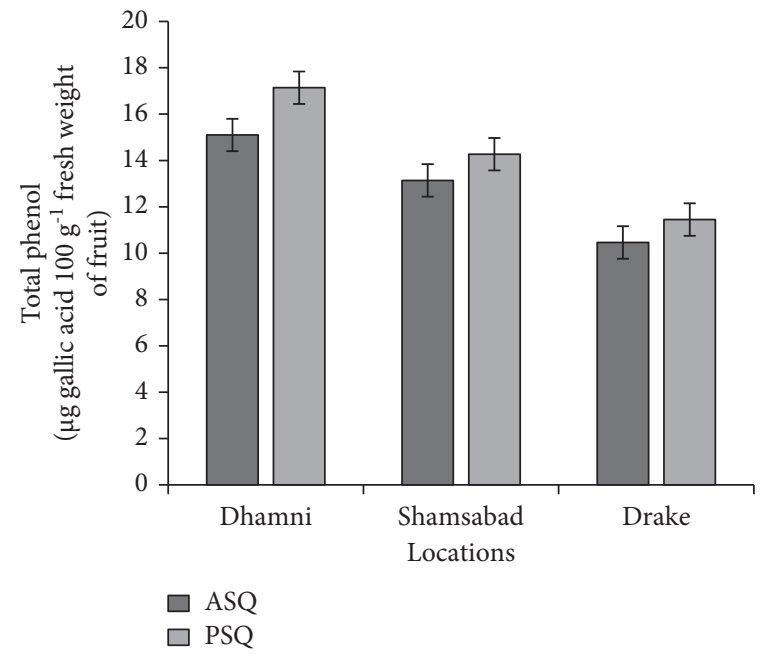

(a)

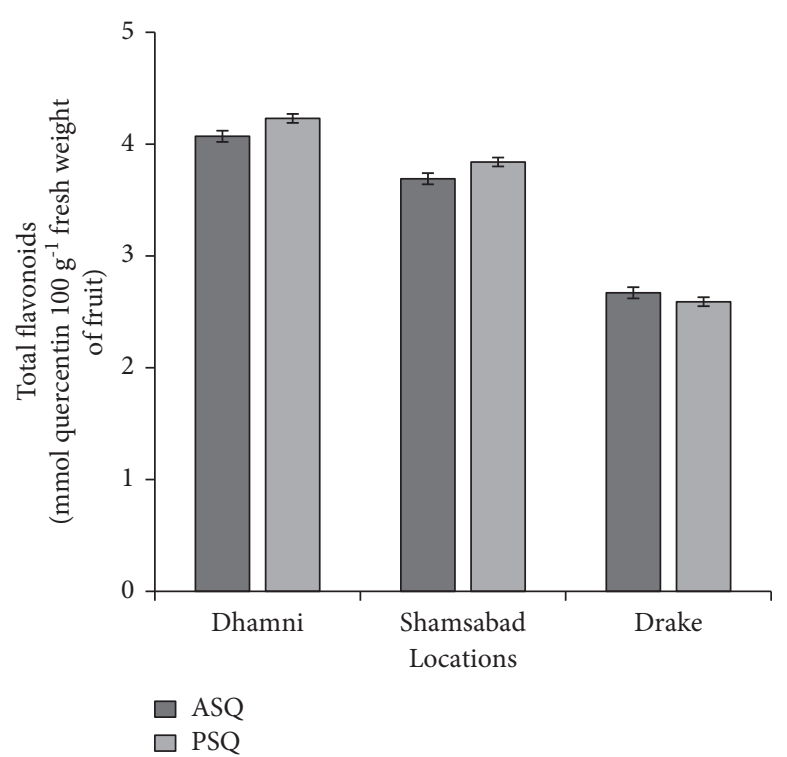

(b)

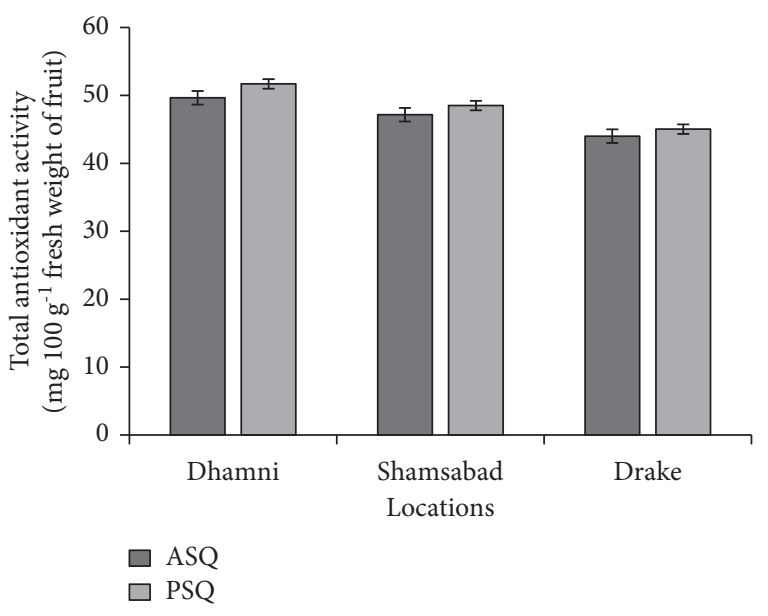

(c)

Figure 2: Effect of different elevations on (a) total phenols, (b) total flavonoids, and (c) total antioxidant activity of two different quince ecotypes. ASQ: apple-shaped quince; PSQ: pear-shaped quince. Vertical bars indicate standard error of means ( \pm SEM) for three replicates.

TABle 3: Mineral nutrients of soil and two quince ecotypes from three different locations of Rawalakot, Azad Jammu and Kashmir.

\begin{tabular}{|c|c|c|c|c|c|c|c|c|c|c|c|c|c|}
\hline \multirow{2}{*}{ Fruit shape } & \multirow{2}{*}{ Locations } & \multicolumn{6}{|c|}{ Soil } & \multicolumn{6}{|c|}{ Fruit } \\
\hline & & $\mathrm{N}$ & $\mathrm{P}$ & $\mathrm{Cu}$ & $\mathrm{Fe}$ & $\mathrm{Zn}$ & $\mathrm{pH}$ & $\mathrm{N}$ & $\mathrm{P}$ & $\mathrm{Cu}$ & $\mathrm{Fe}$ & $\mathrm{Zn}$ & $\mathrm{pH}$ \\
\hline \multirow{3}{*}{ ASQ } & Dhamni & 251.7 & 94.5 & 1.61 & 71.59 & 3.66 & 8.1 & $66.3 \mathrm{ab}$ & $19.1 \mathrm{ab}$ & $1.18 \mathrm{ab}$ & $1.52 \mathrm{ab}$ & $1.99 \mathrm{ab}$ & $3.31 \mathrm{c}$ \\
\hline & Shamsabad & 222.1 & 70.1 & 1.41 & 66.59 & 3.40 & 7.8 & $64.1 \mathrm{~b}$ & $18.1 \mathrm{~b}$ & $0.82 \mathrm{c}$ & $1.06 c$ & $1.22 \mathrm{bc}$ & $3.35 \mathrm{c}$ \\
\hline & Drake & 136.0 & 35.5 & 1.09 & 41.46 & 1.30 & 7.4 & $60.8 \mathrm{c}$ & $15.15 c$ & $0.32 \mathrm{~d}$ & $0.19 \mathrm{~d}$ & $0.36 \mathrm{~d}$ & $3.44 \mathrm{~b}$ \\
\hline \multirow{3}{*}{ PSQ } & Dhamni & 298.1 & 99.8 & 2.23 & 89.23 & 5.68 & 8.7 & $66.7 \mathrm{a}$ & $19.77 \mathrm{a}$ & $1.29 \mathrm{a}$ & $1.62 \mathrm{a}$ & $2.27 \mathrm{a}$ & $3.34 \mathrm{bc}$ \\
\hline & Shamsabad & 256.2 & 84.1 & 1.98 & 74.58 & 4.23 & 8.1 & $64.4 \mathrm{~b}$ & $18.5 b$ & $0.97 b c$ & $1.19 \mathrm{bc}$ & $1.48 \mathrm{~b}$ & $3.37 \mathrm{ab}$ \\
\hline & Drake & 221.3 & 46.7 & 1.56 & 49.34 & 2.76 & 7.2 & $61.1 \mathrm{c}$ & $15.63 c$ & $0.44 \mathrm{~d}$ & $0.29 \mathrm{~d}$ & $0.62 \mathrm{~cd}$ & $3.49 \mathrm{a}$ \\
\hline \multicolumn{2}{|c|}{ LSD } & - & - & - & - & - & - & 2.23 & 1.03 & 0.30 & 0.42 & 0.78 & 0.12 \\
\hline \multicolumn{2}{|c|}{ SD } & \pm 15.6 & \pm 24.4 & \pm 0.39 & \pm 16.4 & \pm 1.5 & \pm 0.6 & - & - & - & - & - & - \\
\hline
\end{tabular}

Note. Means with different letters are significantly different $(P \leq 0.05)$ from each other. ASQ: apple-shaped quince; PSQ: pear-shaped quince; LSD: LSD value; SD: standard deviation.

extended invasion of nutrients and water to fruit [14]. Increased nutrient contents such as nitrogen contents in the soil are helpful in increased size of the fruit [15]. However, $\mathrm{N}$ deficiency leads to poor plant growth [16], small fruit size [17], reduced photosynthetic capacity [18], and production [19]. Nitrogen metabolism is one of the basic processes of 
TABLE 4: Correlation among different mineral nutrients of soil and fruit of quince.

\begin{tabular}{|c|c|c|c|c|c|c|c|c|c|c|c|c|}
\hline & & \multicolumn{5}{|c|}{ Soil } & \multicolumn{5}{|c|}{ Fruit } & \multirow{2}{*}{$\begin{array}{c}\text { Fruit quality index } \\
\text { TA }\end{array}$} \\
\hline & & $\mathrm{N}$ & $\mathrm{P}$ & $\mathrm{Cu}$ & $\mathrm{Fe}$ & $\mathrm{Zn}$ & $\mathrm{N}$ & $\mathrm{P}$ & $\mathrm{Cu}$ & $\mathrm{Fe}$ & $\mathrm{Zn}$ & \\
\hline \multirow{4}{*}{ Soil } & $\mathrm{P}$ & 0.898 & & & & & & & & & & \\
\hline & $\mathrm{Cu}$ & 0.929 & 0.799 & & & & & & & & & \\
\hline & $\mathrm{Fe}$ & 0.923 & 0.926 & 0.878 & & & & & & & & \\
\hline & $\mathrm{Zn}$ & 0.968 & 0.902 & 0.948 & 0.971 & & & & & & & \\
\hline \multirow{5}{*}{ Fruit } & $\mathrm{N}$ & 0.841 & 0.985 & 0.719 & 0.943 & 0.8617 & & & & & & \\
\hline & $\mathrm{P}$ & 0.985 & 0.986 & 0.767 & 0.973 & 0.9012 & 0.986 & & & & & \\
\hline & $\mathrm{Cu}$ & 0.883 & 0.996 & 0.782 & 0.962 & 0.8983 & 0.994 & 0.990 & & & & \\
\hline & $\mathrm{Fe}$ & 0.849 & 0.990 & 0.731 & 0.953 & 0.8703 & 0.996 & 0.995 & 0.994 & & & \\
\hline & $\mathrm{Zn}$ & 0.968 & 0.975 & 0.790 & 0.955 & 0.9015 & 0.990 & 0.975 & 0.996 & 0.971 & & \\
\hline \multirow{2}{*}{ Fruit quality index } & TA & 0.854 & 0.964 & 0.760 & 0.938 & 0.8825 & 0.983 & 0.957 & 0.981 & 0.967 & 0.993 & \\
\hline & TSS & 0.787 & 0.527 & 0.851 & 0.555 & 0.6976 & 0.404 & 0.438 & 0.489 & 0.411 & 0.510 & 0.45 \\
\hline
\end{tabular}

Note. N: nitrogen; P: phosphorus; Cu: copper; Fe: iron; Zn: zinc; TA: titratable acidity; TSS: total soluble solids.

plant physiology which controls many cellular activities in plants [20] and is crucial for stress tolerance [21]. Plants absorb $\mathrm{N}$ as either nitrate or ammonium and then convert these to various amino acids [22]. Therefore, the activities of $\mathrm{N}$ assimilating enzymes play a significant role in maintaining growth and development [23]. Our results showed a positive correlation between soil and fruit nitrogen contents. These high nitrogen contents in the soil result in increased fruit weight. Correlation table showed a positive correlation between soil nitrogen contents and fruit weight. From these results, it is clear that increased nitrogen contents in the soil result in increased uptake of nutrients from the soil which leads to enhanced chlorophyll contents resulting in high photosynthesis for developing ovules [24].

Results of fruit quality indices showed the balance of acidity and sugars. These fruit quality indices are cultivarspecific [25]. But these quality indices can be modified by growing conditions and nutrition rate of soil. The difference in titratable acidity could be due to weather conditions such as temperature, relative humidity, rainfall, and altitude. In our results, TA and TSS increased with the increase in elevation [26]. The decrease in TSS is due to the use of simple sugars during cellular respiration [27]. Meanwhile, the difference in TA and TSS with fruit shape might be due to the endogenous hormones because the level of hormones varies in different accessions [28]. The level of hormones and cellular respiration is highly dependent on amount of nutrients in the soil. In our results, a positive correlation was observed among these quality indices, as well as fruit and soil nutritional status. Phosphorus played an important role in accumulation of soluble solids (mainly sugars) [29]. The increase in phosphorus in soil results in increased storage capacity and transfers energy to the cells which in return donates electron to maintain biochemical phase of photosynthesis. Therefore, an increase in photosynthesis activity allows the solutes to move inside the plants and facilitate the expression of plants to accumulate sugars inside the fruit [30]. Low levels of phosphorus in soil result in low concentrations of galactaric acid, lysine, vitamin C, proline, and citrate and thus results in a significant change in bioactive compounds in different fruits [31]. Our results showed that soils and fruits of higher elevations are rich in micro- and macronutrients (Table 3). Meanwhile, correlation analysis (Table 4) showed that one unit increase in P results in 0.964 units increase in TA and 0.527 units increase in TSS. Meanwhile, among microelements, $\mathrm{Zn}$ had the largest share in increased quality indices [32]. Accumulation of $\mathrm{Zn}$ in soil results in prohibited activity of proteinase and dehydrogenase enzymes in the fruits. These enzymes are responsible for early fruit maturity and deteriorate the fruit quality attributes [33]. Copper is another important micronutrient, which plays an important role in accumulation of TSS and TA content [34]. Cu increases the catalase activity in plants which in return reduces the metabolic activities in fruits and helps in accumulation of sugars and acids [35]. Thus, the increase in $\mathrm{Cu}$ and $\mathrm{Zn}$ also played a positive role in increase in fruit quality indices.

The amount of vitamin $C$ in both ecotypes was low at low elevations and higher at high elevations. This may be due to climatic and geographical factors that include rainfall, temperature, and light intensity. It is generally stated that the increase in vitamin $C$ increases with the increase in light intensities [2]. The increase in $\mathrm{Cu}$ content in the soil is also helpful in increased vitamin C [36]. Our results in Table 3 show that copper contents are maximum at higher altitude, which in turn increase the amount of vitamin $C$ in the fruits harvested from higher locations. The accumulation of vitamin C in fruits is due to decrease of different acids such as fumaric acid and malic acid. This decrease in acids results in prime carbon fluxes during fruit ripening and high respiration. This increased respiration during maturation process is highly influenced by $\mathrm{Cu}$ compounds, which yields increased vitamin $\mathrm{C}$ contents [37]. Similarly, the $\mathrm{pH}$ and amount of crude fiber in fruit are highly influenced by elevation. $\mathrm{pH}$ of quince fruit normally ranges between 3.3 and 3.5. Fruit quality is highly influenced by $\mathrm{pH}$ of fruits, as less acidic fruits are more flavorful [37]. The increase in fruit $\mathrm{pH}$ is due to conversion of acids into sugars which is later used in cellular respiration to get energy. This results in declining of acidity and increase in $\mathrm{pH}$ [27]. This transformation of acids in simple sugars is induced by increased $\mathrm{Cu}$ contents [34]. It was reported earlier that acids accumulate in the fruits due to the changes derived during glycolysis and Krebs cycle as these changes are predominant carbon fluxes during 
fruit maturation process. The increased respiration during fruit maturity results in increased intermediate products of Krebs cycle [35]. It might be possible that $\mathrm{Cu}$ content influences fruit respiration which is responsible for conversion of acids into simple sugars [36]. Our results showed that $\mathrm{Cu}$ contents are more in soils and fruits at higher elevation than at lower elevations. Fruits harvested from higher elevation showed maximum fiber contents. These results are similar to the results of Coronado et al. [9], who reported the positive correlation between higher elevation and fruit fiber. In another study conducted by Rodríguez-Guisado et al. [38], the amount of fiber in fruit is negatively correlated with moisture contents of fruits irrespective to environmental factors. Ash contents are positively correlated with the fiber contents of fruits [39]. A significant variation in ash content is observed in our results. The decrease in ash content with low elevation might be due to high respiration rate and low mineral uptake. Our results showed that mineral contents are less at lower elevation (Table 3). The differences in fiber and ash contents are also genotype-dependent and the amount of variability in genotype is ascertained for quality improvement programs [28].

In this study, bioactive compounds showed a positive correlation with elevation. Results showed that higher elevations have more mineral contents, which helps in increased phenols, flavonoids, and antioxidant activities. But the difference in amount of bioactive compounds with shape might be due to the difference in environmental factors such as annual rainfall, sunshine, and soil nutritional status or it might be due to the difference in genetic makeup [40]. Zheng et al. [41] reported that the phenolic contents increase more with more exposure to sunlight. Phenols are influential chain breaching antioxidants and contribute straight in oxidative action [42]. Phenolic compounds are also reported as powerful antimicrobial agents which might explain the importance of high phenolic compounds in quince fruit. Moreover, several studies showed highly positive correlations among total phenolic contents and total antioxidants activities $[43,44]$. From these studies, it is clear that antioxidant activities are mainly due to phenols. In another study, Lópes-Vargas et al. [34] demonstrate that vitamin C in fruits is responsible for the high antioxidant activity. Phenols and flavonoids are the compounds that trigger the synthesis of secondary metabolites. These metabolites help plants in reducing oxidative stress by triggering the elimination of singlet oxygen and $\mathrm{H}_{2} \mathrm{O}_{2}$ [45]. It was earlier reported that foliar application of $\mathrm{Zn}$ results in increased phenolic contents in pomegranate [46]. Meanwhile application of $\mathrm{Zn}$ nanoparticles in soil results in stimulated antioxidant activity in tomato and beans [47]. Our results of mineral elements in soil are in line with previous research, which showed that higher elevations have more mineral contents which helps in increased phenols, flavonoids, and antioxidant activities. Soil is the major source of energy as it provides heat to plants during night and this favorable night temperature helps in decomposition and mineralization of organic matter. Due to high soil temperature and moisture, availability of water soluble phosphorus increased which in turn helped in uptake of other mineral contents [48]. These minerals are responsible for increased bioactive compounds in fruits. It is supposed that such variations in mineral contents are related to intrinsic characteristics of each cultivar. These results are, therefore, important in the choice of a cultivar with superior properties for consumption and even for facilitating genetic improvements to obtain superior cultivars. Table 4 shows Pearson correlation coefficients, which represent highly significant $(P \leq 0.05)$ relationship among all mineral contents. Increased amount of zinc is responsible for synthesis of carbohydrates and also participates in different chemical reactions. All these mineral elements are highly positively correlated with each other (Table 4). Mineral contents of fruits are highly dependent on climatic conditions, soil fertility, and fruit cultivar [49]. Some minerals such as phosphorus combine with organic acids of fruit and influence buffering capacity, which results in increase of acidity of fruits [50]. Meanwhile, copper acts as an activator for respiration and photosynthetic enzymes. This element indirectly helps in formation of sugars through photosynthesis and organic acids through respiration [34]. These increased mineral contents in soil and fruit have a positive effect on fruit quality indices (Table 4). These results of analysis of relationship between nutrient contents and fruit quality indices showed that each group of micro- and macroelements contributed in sugars and acidity of fruits [29].

Based on this model and related functions, it is possible to predict the value of quince quality indices with multiple practical advantages. Quince quality indices may be predicted with the elevation and mineral contents of the soil.

\section{Conclusions}

It could be concluded from the present study that quince fruit quality can be enhanced by fertilizing with mineral elements and planting at high elevations. These results also demonstrate that soils of higher elevations could be used for breeding of quince for better yield and quality fruits.

\section{Data Availability}

All relevant data have been provided in the manuscript. If any additional details are required, the authors will gladly provide those.

\section{Disclosure}

Noosheen Zahid's current address is Department of Horticulture, Faculty of Agriculture, University of Poonch Rawalakot, Azad Jammu and Kashmir, Pakistan.

\section{Conflicts of Interest}

The authors declare no conflicts of interest.

\section{Acknowledgments}

The authors are highly thankful to the local people for providing quince fruits free of cost for this study. 


\section{References}

[1] A. F. Vinha, M. O. Soares, T. Herdeiro, and M. Machado, "Chemical composition and antioxidant activity of Portuguese Diospyrus kaki fruit by geo graphical origins," Journal of Agricultural Sciences, vol. 4, pp. 281-289, 2012.

[2] S. Correia, B. Gonçalves, A. Aires et al., "Effect of harvest year and altitude on nutritional and biometric characteristics of blueberry cultivars," Journal of Chemistry, vol. 2016, Article ID 8648609, 12 pages, 2016.

[3] A. Wojdyło, M. Teleszko, and J. Oszmiański, “Antioxidant property and storage stability of quince juice phenolic compounds," Food Chemistry, vol. 152, pp. 261-270, 2014.

[4] R. Sharma, V. K. Joshi, and C. Rana, "Nutritional composition and processed products of quince (Cydonia oblonga Mill)," Indian Journal of Natural Products and Resources, vol. 2, pp. 354-357, 2011.

[5] P. J. Szychowski, S. Munera-Picazo, A. Szumny, Á. A. Carbonell-Barrachina, and F. Hernández, "Quality parameters, bio-compounds, antioxidant activity and sensory attributes of Spanish quinces (Cydonia oblonga Miller)," Scientia Horticulturae, vol. 165, pp. 163-170, 2014.

[6] N. Ali, Y. Abbas, A. Ali, M. Shahnawaz, N. Hussain, and A. Hussain, "Physio-chemical nutritional and sensory evaluation of local quince fruit of Nomal village, Gilgit-Baltistan, Pakistan," International Journal of Nutrition and Food Sciences, vol. 4, no. 6, pp. 600-608, 2015.

[7] R. Madi, T. Szabo, and S. Brozik, "Renewed assortment of quince varieties in Hungary," Journal of Horticultural Science, vol. 28, pp. 26-31, 1996.

[8] M. Leonel, S. Leonel, S. Leonel et al., "Characteristics of quince fruits cultivars' (Cydonia oblonga Mill.) grown in Brazil," Australian Journal of Crop Science, vol. 10, no. 5, pp. 711-716, 2016.

[9] A. Parra-Coronado, G. Fischer, and J. H. Camacho-Tamayo, "Development and quality of pineapple guava fruit in two locations with different altitudes in Cundinamarca, Colombia," Bragantia, vol. 74, no. 3, pp. 359-366, 2015.

[10] A. Ali, N. Zahid, S. Manickam, Y. Siddiqui, and P. G. Alderson, "Double layer coatings: a new technique for maintaining physico-chemical characteristics and antioxidant properties of dragon fruit during storage," Food and Bioprocess Technology, vol. 7, no. 8, pp. 2366-2374, 2014.

[11] P. Sáez-Plaza, M. J. Navas, S. Wybraniec, T. Michałowski, and A. G. Asuero, "An overview of the kjeldahl method of nitrogen determination. Part II. Sample preparation, working scale, instrumental finish, and quality control," Critical Reviews in Analytical Chemistry, vol. 43, no. 4, pp. 224-272, 2013.

[12] S. Follain, C. Schvartz, P. Denoroy et al., "A method for assessing available phosphorus content in arable topsoils over large spatial scales," Agronomy for Sustainable Development, vol. 29, no. 2, pp. 371-379, 2009.

[13] T. Mahmood, F. Anwar, T. Iqbal, I. A. Bhatti, and M. Ashraf, "Mineral composition of strawberry, mulberry and cherry fruits at different ripening stages as analyzed by inductively coupled plasma-optical emission spectroscopy," Journal of Plant Nutrition, vol. 35, no. 1, pp. 111-122, 2012.

[14] A. A. Polat, C. Durgaç, and O. Kamiloğlu, "Determination of fruit quality parameters of sweet cherries grown in high elevation regions in Hatay, Turkey," Acta Horticulturae, vol. 10, no. 795, pp. 873-876, 2008.

[15] A. Mattos Jr., J. A. Quaggio, H. Cantarella, and A. K. Alva, "Nutrient content of biomass components of Hamlin sweet orange trees," Scientia Agricola, vol. 60, no. 1, pp. 155-160, 2003.

[16] M. T. Grzesiak, T. Hura, S. Grzesiak, K. Kaczanowska, and P. Szczyrek, "Influence of nitrogen deficiency or excess on a root system structure of maize and triticale seedlings grown under low and high soil density," Journal of Agronomy and Crop Science, vol. 204, no. 2, pp. 196-208, 2017.

[17] J. Ng'etich, O. K. A. N. Niyokuri, J. J. Rono, A. Fashaho, and J. O. Ogweno, "Effect of different rates of nitrogen fertilizer on the growth and yield of Zucchini (Cucurbita pepo cv. Diamant L.) hybrid F1 in Rwandan high altitude zone," The International Journal of Agriculture and Crop Sciences, vol. 51, pp. 54-62, 2013.

[18] T. Antal, H. Mattila, M. Hakala-Yatkin, T. Tyystjärvi, and E. Tyystjärvi, "Acclimation of photosynthesis to nitrogen deficiency in Phaseolus vulgaris," Planta, vol. 232, no. 4, pp. 887-898, 2010.

[19] Q. Xiong, G. Tang, L. Zhong, H. He, and X. Chen, "Response to nitrogen deficiency and compensation on physiological characteristics, yield formation, and nitrogen utilization of rice," Frontiers of Plant Science, vol. 9, p. 1075, 2018.

[20] M. Ashraf, S. M. Shahzad, M. Imtiaz, and M. S. Rizwan, "Salinity effects on nitrogen metabolism in plants-focusing on the activities of nitrogen metabolizing enzymes: a review," Journal of Plant Nutrition, vol. 41, no. 8, pp. 1-17, 2018.

[21] Y.-B. Teng, Y.-J. Li, P. Fang, and G.-X. La, "Characterization of nitrogen metabolism in the low-nitrogen tolerant lnt1 mutant of Arabidopsis thaliana under nitrogen stress," Pedosphere, vol. 20, no. 5, pp. 623-632, 2010.

[22] L. Giagnoni, R. Pastorelli, S. Mocali, M. Arenella, P. Nannipieri, and G. Renella, "Availability of different nitrogen forms changes the microbial communities and enzyme activities in the rhizosphere of maize lines with different nitrogen use efficiency," Applied Soil Ecology, vol. 98, pp. 30-38, 2016.

[23] M. Singh, V. P. Singh, and S. M. Prasad, "Nitrogen modifies $\mathrm{NaCl}$ toxicity in eggplant seedlings: assessment of chlorophyll a fluorescence, antioxidative response and proline metabolism," Biocatalysis and Agricultural Biotechnology, vol. 7, pp. 76-86, 2016.

[24] M. Heidari and M. M. Mohammad, "Effect of rate and time of nitrogen application on fruit yield and accumulation of nutrient elements in Momordica charantia," Journal of the Saudi Society of Agricultural Sciences, vol. 11, no. 2, pp. 129-133, 2012.

[25] K. Hecke, K. Herbinger, R. Veberič et al., "Sugar-, acid- and phenol contents in apple cultivars from organic and integrated fruit cultivation," European Journal of Clinical $\mathrm{Nu}$ trition, vol. 60, no. 9, pp. 1136-1140, 2006.

[26] G. Calvo, "Effect of 1-methyl cyclopropene (1-MCP) in apples $\mathrm{cv}$. Net delicious reaped with three states of maturity and conserved in cold conventional and atmosphere controlled," Journal of Agricultural Technology, vol. 33, pp. 3-26, 2004.

[27] W. Klunklin and G. Savage, "Effect on quality characteristics of tomatoes grown under well-watered and drought stress conditions," Foods, vol. 6, no. 8, p. 56, 2017.

[28] N. Nisar, L. Li, S. Lu, N. C. Khin, and B. J. Pogson, "Carotenoid metabolism in plants," Molecular Plant, vol. 8, no. 1, pp. 68-82, 2015.

[29] C. Jivan and F. Sala, "Relationship between tree nutritional status and apple quality," Horticultural Science, vol. 41, no. 1, pp. 1-9, 2014.

[30] G. S. D. Lima, A. R. P. D. Silva, F. V. D. S. Sá, H. R. Gheyi, and L. A. D. A. Soares, "Physicochemical quality of fruits of west 
Indian cherry under saline water irrigation and phosphate Fertilization1," Revista Caatinga, vol. 33, no. 1, pp. 217-225, 2020.

[31] Q. Bai, Y. Shen, and Y. Huang, “Advances in mineral nutrition transport and signal transduction in Rosaceae fruit quality and postharvest storage," Frontiers of Plant Science, vol. 12, 2021.

[32] Z. H. Pinedo-Guerrero, A. D. Hernández-Fuentes, H. OrtegaOrtiz, A. Benavides-Mendoza, G. Cadenas-Pliego, and a. A. Juárez-Maldonado, "Cu nanoparticles in hydrogels of chitosan-PVA affects the characteristics of post-harvest and bioactive compounds of jalapeño pepper," Molecules, vol. 22, no. 6, pp. 926-940, 2017.

[33] A. A. Rahi, M. A. Anjum, J. Iqbal Mirza et al., "Yield enhancement and better micronutrients uptake in tomato fruit through potassium humate combined with micronutrients mixture," Agriculture, vol. 11, no. 4, pp. 357-370, 2021.

[34] E. López-Vargas, H. Ortega-Ortíz, G. Cadenas-Pliego et al., "Foliar application of copper nanoparticles increases the fruit quality and the content of bioactive compounds in tomatoes," Applied Sciences, vol. 8, no. 7, pp. 1020-1035, 2018.

[35] G. Oms-Oliu, M. L. A. T. M. Hertog, B. Van de Poel, J. Ampofo-Asiama, A. H. Geeraerd, and B. M. Nicolaï, "Metabolic characterization of tomato fruit during preharvest development, ripening, and postharvest shelf-life," Postharvest Biology and Technology, vol. 62, no. 1, pp. 7-16, 2011.

[36] A. Juarez-Maldonado, H. Ortega-Ortíz, F. Pérez-Labrada, and G. Cadenas-Pliego, "Cu nanoparticles absorbed on chitosan hydrogels positively alter morphological, production and quality characteristics of tomato," Journal of Applied Botany and Food Quality, vol. 89, pp. 183-189, 2016.

[37] Y. Wang, M. Chantreau, R. Sibout, and S. Hawkins, "Plant cell wall lignification and monolignol metabolism," Frontiers of Plant Science, vol. 4, pp. 220-230, 2013.

[38] I. Rodríguez-Guisado, F. Hernández, P. Melgarejo, P. Legua, R. Martínez, and J. J. Martínez, "Chemical, morphological and organoleptical characterisation of five Spanish quince tree clones (Cydonia oblonga Miller)," Scientia Horticulturae, vol. 122, no. 3, pp. 491-496, 2009.

[39] C. Patané, "Variation and relationships among some nutritional traits in Sicilian genotypes of chickpea (Cicer arietnum L.)," Journal of Food Quality, vol. 29, pp. 282-293, 2005.

[40] F. Hanen, K. Riadh, O. Samia, G. Sylvain, M. Christian, and A. Chedly, "Interspecific variability of antioxidant activities and phenolic composition in Mesembryanthemum genus," Food and Chemical Toxicology, vol. 47, no. 9, pp. 2308-2313, 2009.

[41] J. Zheng, B. Yang, S. Tuomasjukka, S. Ou, and H. Kallio, "Effects of latitude and weather conditions on contents of sugars, fruit acids, and ascorbic acid in black currant (ribes nigrum L.) juice," Journal of Agricultural and Food Chemistry, vol. 57, no. 7, pp. 2977-2987, 2009.

[42] M. N. Nor Qhairul Izzreen and A. B. Mohd Fadzelly, "Phytochemicals and antioxidant properties of different parts of Camellia sinensis leaves from Sabah Tea Plantation in Sabah Malaysia," International Food Research Journal, vol. 20, pp. 307-312, 2013.

[43] M. F. Abu Bakar, M. Mohamed, A. Rahmat, and J. Fry, "Phytochemicals and antioxidant activity of different parts of bambangan (Mangifera pajang) and tarap (Artocarpus odoratissimus)," Food Chemistry, vol. 113, no. 2, pp. 479-483, 2009.

[44] L. T. Ling, A. K. Radhakrishnan, T. Subramaniam, H. M. Cheng, and U. D. Palanisamy, "Assessment of antioxidant capacity and cytotoxicity of selected Malaysian plants," Molecules, vol. 15, no. 4, pp. 2139-2151, 2010.

[45] I. Hernández, L. Alegre, F. Van Breusegem, and S. MunnéBosch, "How relevant are flavonoids as antioxidants in plants?" Trends in Plant Science, vol. 14, no. 3, pp. 125-132, 2009.

[46] S. Davarpanah, A. Tehranifar, G. Davarynejad, J. Abadía, and R. Khorasani, "Effects of foliar applications of zinc and boron nano-fertilizers on pomegranate (Punica granatum cv. Ardestani) fruit yield and quality," Scientia Horticulturae, vol. 210, pp. 57-64, 2016.

[47] C. García-Gómez, A. Obrador, D. González, M. Babín, and M. D. Fernández, "Comparative effect of $\mathrm{ZnO} N P s, \mathrm{ZnO}$ bulk and $\mathrm{ZnSO} 4$ in the antioxidant defences of two plant species growing in two agricultural soils under greenhouse conditions," The Science of the Total Environment, vol. 589, pp. 11-24, 2017.

[48] B. Onwuka and B. Mang, "Effect of soil temperature on some soil properties and plant growth," Advances in Plants \& Agriculture Research, vol. 8, pp. 34-37, 2018.

[49] V. Nour, I. Trandafir, and M. E. Ionica, "Ascorbic acid, anthocyanins, organic acids and mineral content of some black and red currant cultivars," Fruits, vol. 66, no. 5, pp. 353-362, 2011.

[50] A. A. Kader, "Flavor quality of fruits and vegetables," Journal of the Science of Food and Agriculture, vol. 88, no. 11, pp. 1863-1868, 2008. 